\title{
Novice Versus Experienced Teachers: How They Transform Their Vulnerability Into Professional Identity in an Indonesian Junior High School
}

\section{Nancy Agatha Florida ${ }^{*}$, Concilianus Laos Mbato ${ }^{2}$}

1,2 Sanata Dharma University,

\section{A R T I C L E I N F 0}

Article history:

Received 29 December 2019

Received in revised

Form 01 January 2020

Accepted 18 January

2020

Available online 28

February 2020

Keywords:

education quality;

vulnerability;

professional identity

construction; burn out;

novice and experienced

teachers

\section{A B S T R A C T}

The quality of education is influenced by many factors, one of which is the quality of the teachers. In the spirit of fostering a strong and resilient young generation, teachers in the capital city of Nusa Tenggara Timur (NTT), Kupang, attempted to break through their limitations in order to form their identity. This research investigated how novice and experienced teachers shifted their vulnerability into professional identity and to what extent this strategy impacted on their professional identity construction in a Junior High School in Kupang. This research presented a thematic analysis on their expectation and anxiety, their strategies and how these strategies helped them to build their identity. Results from data analysis clearly indicated that without critical reflections and actions, both novice and experienced teachers could undergo burnt out when dealing with their vulnerability. 


\section{Introduction}

Citizens of East Nusa Tenggara Timur province, Indonesia (NTT) is still struggling to improve the quality of education. According to the former Indonesian Minister of Education and Culture, NTT is in the bottom three after Papua and West Papua province (Seo, 2018). This statement drew some comments from politicians. One of the parliament members from the region, Benny Harman, argues that many factors influence education quality in the province. The first is the demographic condition of the province itself. NTT is the largest island province of Indonesia with slow-paced infrastructure development and low connectivity. The second is about the educational funding from the central government, which is still concentrated in Java. He added that the inadequate honorary teacher salaries, poverty and underdevelopment issues affect the quality of education in NTT (Harman, 2017).

Kupang as the capital city of NTT province gives a portrayal of how the local government attempts to ameliorate the standard of their teaching. Many attempts are being carried out to improve the quality, both the facilities and the human resources. Teachers have an important role to improve the quality of education in the society and this role is grounded in their expertise on knowledge, skills and attitudes (Kelchtermans, 2013, pp. 257-258). Teaching is not only how someone transfers knowledge to others but also how they understand and construct themselves as a teacher. The clarification of the teacher's concept will develop through reflective attitudes and skills.

Self-reflection is important to do in order to help teachers to recognize their strengths and weaknesses. Since teaching is an emotional work, teachers are demanded to deal with stress and also maintain a healthy relationship among themselves and with their students. How teachers regulate their emotion is likely to make them remain committed and able to teach to their best. When teachers do selfreflection regularly, they will know themselves better, recognize how their vulnerability shapes and also embrace the idea that they are also the learners in this teaching process (Alsup, 2018, p.15). Palmer (2003) states whenever teaching becomes all pain and no joy, we have to identify what our strengths are. Instead of focusing on our failings, we have to focus on our strengths and how we bounce back again. While facing tensions or vulnerability, teachers must have strategic plans on how to overcome them and how they develop their professional identity.

Teaching as a career path can sometimes be very challenging. The pressures such as heavy workload, behavioral problems of the students, inadequate salary, demanding parents or not cooperative workplace's environment will emotionally drain teachers' energy. Palmer $(2003$, p.13) believes that all of those pressures can be handled by the teacher's identity and integrity. This does not imply that the teacher should use it to cover their own vulnerabilities or confusion, but that through the teacher's identity and integrity, they could recognize and strengthen their weaknesses and limits. In other words, identity is a hybrid combination of the internal self (the genetic from our parent) and external self (sociocultural) which make us who we are. However, integrity is the harmony of what we believe and how we act. It is how we see ourselves and why we want to be a teacher. Both of them will represent the wholeness of our well-being and it can be achieved over time.

In the last decade, there were several studies investigating how teachers acknowledge their vulnerability and develop their professional identity. Hamman, Gosselin, Romano and Bunuan (2010) use possible-selves theory to understand the identity development of new teachers. They analyze how futureoriented teachers provide identity and reveal the expectations and fears facing beginning teachers in a public university in the Southwestern United States. The findings of the study suggest that new teachers' possible selves may be classified into four primary categories, i.e., professionalism, classroom management, interpersonal school relations, and instruction (Hamman, et.al, 2010).

Friesen and Besley (2013) analyzed how teacher identity develops in the first year of teacher education from a social psychological perspective. Their research concludes that personal identity development and social identity were significantly associated. The teacher education programs have two roles; to facilitate students' identity development at both personal and social level and to challenge the students' perception about the teacher and why they want to be a teacher. On the other hand, Pillen, Beijaard, and den Brok (2013) draw the tensions and how the teachers deal with these. The teacher identity tension happens from unbalancing personal and professional side or in between what they desire and what it is in reality. Mostly, teachers face these problems with the feelings of anger or helplessness and they tried to search the solution themselves or share stories with their colleagues.

How teachers deal with emotion is examined by Song (2016). She interviews five secondary English teachers in South Korea. Each of them presented their conflicting stories in their classrooms. Song analyzed how their vulnerability affected themselves and their students' competence and curriculum, and how their emotion affected their pedagogical and self-transformation. 
The studies cited above demonstrated how teachers dealt their weaknesses and transformed their professional identity. None of these studies show the comparison between novice and experienced teachers, let alone in the context of Indonesia or in East Nusa Tenggara province. As a province which is still striving to improve the quality of its education, the researchers find that this research is important to fill in the gap in the literature on teacher professional developments, in particular regarding the teachers' strategies to acknowledge their weaknesses and develop a professional identity as a teacher. To this end, the writer offers theories of vulnerability, teacher identity, and identity development. According to Jun, Issa, Feng, and Zheng Zhi Lian (2018) identity develops through time.

"Teacher identity could shift with every new teaching skill, new expectation from students and teachers, new social context, new question and new idea. Its ever-changing nature presents an on-going challenge for teachers" (p.46).

The goal of this paper is to figure out the identity differences between the novice and experienced teachers, how they acknowledge the vulnerability and develop their professional identity in a junior high school in Kupang, NTT. To achieve this, the researchers addressed two situations that shaped teacher identity and professional vulnerability. They are: (a) the critical events which trigger their vulnerability; and (b) the current reform on teacher identity. Their awareness about the concept of vulnerability is likely to facilitate the teacher to do self-reflection about the early influences on their strengths and weaknesses' recognition, and; whether these tensions bring a new set of values and beliefs to construct their identity for teaching. If it does, it would be important to investigate how teachers understand and experience these ups and downs through the lens of their professional identity, as well as how they experience the transformation which is shaped by the experiences of vulnerability (Ulvik \& Langrgen, 2012).

This research aimed to answer these following questions:

- What are the strategic plans used by the Indonesian novice and experienced teachers in order to transform their vulnerability into professional identity?

- To what extent do these strategies impact on professional identity construction?

Teacher Vulnerability

Vulnerability is a condition when teachers find themselves in the situation of lacking control while at the same time, they have to regulate their emotions (Kelchtermans, 2013; Kwo, 2018). In addition Liew (2018) argues:

"Painful but necessary, embracing vulnerability as part of change entails feelings of self-doubt, anxiety, loss and uncertainty. Indeed, reculturing for reform is emotionally straining to the extent that it threatens teachers' established beliefs, assumptions and routines" (p.256).

Teacher's vulnerability is the emotional experience which can be influenced by the way people perceive their present situation as it interacts with their identity, beliefs, values, and sense of competence. Lasky (2005) argues that vulnerability can make someone feel defenseless in situations of high anxiety. In these situations, people will have no control or feel powerless over factors that affect their environments, or feel they are being "forced" to act in certain ways which are not in accordance with their own beliefs and values. He claims that,

"It can be an experience of openness and trust, which is necessary for love, experiencing compassion, learning, and relationship building. In these situations, people willingly open themselves to the possibility of embarrassment, loss, or emotional pain because they believe that they, another individual, or a situation will benefit from this openness. A person being willingly open facilitates learning, trust building, and collaboration. In short, a person feels safe in his or her environment to take the risk of losing face and experiencing loss or pain" (p. 901).

Furthermore, Kelchtermans (2013, pp. 265-266) identified three elements of vulnerability in teaching. First, when a teacher has no full control of the situation in the school environment, such as in the regulation or in the quality control. Second, when a teacher is evaluated by the students' test scores and the third is when a teacher cannot make a decision about how to support students' learning development. During their professional job, teachers may find themselves in this fundamental condition that challenges them to properly balance between their self-efficacy and acknowledgment of their personal limitation.

In the Indonesian education context, English teachers are faced with various kinds of demands, such as applying Curriculum K-13, students' various ability at understanding the materials, salary, working hours, language facilitates and infra structure in the school. These burdens are likely to make a teacher vulnerable and if they cannot handle them well, they will experience burn out from her professional job.

Teacher Identity

Teacher identity is the way a teacher sees themselves and how they are recognized by others; the stories that teachers create and tell about their teaching lives (Sloan, 2006). "Identity commitment 
influences teacher agency not only in how they position themselves towards reforms but also in how they act towards reforms" (Tao \& Gao, 2017, p. 353).

Hwang (2007, cited in Miyagamwala, 2015, p.234) states that the teachers who had superior competencies, comfort, empathy, leadership and self-esteem tended to perform better in overall teaching effectiveness. Yet the teachers who performed superior in overall emotional intelligence skills tended to achieve higher teaching effectiveness. Seen this way, teacher identity affects how teachers understand and interact with the school environment, whether it is shaped in the school policy, curriculum, students, or between fellow teachers.

Those explanations about identity show that identity has a connection with emotional intelligence skills. In order to be a successful teacher, one should have an identity. It can be concluded that identity is more than a personal issue; it is a social learning process, lived and negotiated. That is why; identity is not fixed but always changing from time to time especially when the process is difficult and painful. Teachers should develop their professional identity so that they will be able to engage their self into the professional/cultural expectations of what it means to be a teacher (Alsup, 2018, p.15).

\section{Methods}

This research was conducted qualitatively since it aimed to describe teachers' perspectives and their experiences in transforming their vulnerability into professional identity. The data were presented in narrative forms as Creswell $(2014$, p. 254) suggests that "qualitative methods should end with some comments about the narrative that will emerge from the data analysis".

Participants

The participants of the research were English teachers with different lengths of the teaching experiences in one of junior high school in Kupang, NTT province. To protect their confidentiality, pseudonyms were given. The reseacher classified the participants as novice teachers (NTs) and experienced teachers (ETs). The NTs were those who had the English teaching experience under 5 years while ETs had more than 5 years of the teaching experience. The different lengths of the teaching experiences were used in order to give us a clear picture of any specific details on how they formed and achieved their identity.

Data collection and analysis

The researchers used teachers' reflections and semi-structured interview for gathering the information. The participants were asked to reflect about what they believed and how they saw their identity as a teacher and shared their critical incidents while dealing with their vulnerabilities. The semistructured interviews were conducted to help the researchers get the background knowledge of how far the participants acknowledged their strengths and weaknesses and what strategic plans they used to develop their professional identity. It offered an in-depth exploration of the ways teachers understood and experienced their professional vulnerability. The teacher's conception about how they see themselves as a teacher should appear naturally in the act of telling (Kelchtermans, 2013). All participants were asked to explain the critical events which sometimes triggered their vulnerability. Then, the discussion moved to incoming identity goals, standards, and beliefs; emotional episodes; teacher attributions, and identity adjustments. Phone interviews were conducted because of the distance between the researchers and the participants. Each interview was recorded and then transcribed verbatim. A thematic analysis was conducted to analyze the research.

The data was organized in the compare-contrast structure in order to analyze the differences and the similarities between novice and experienced teachers. It aimed to establish the underlining conditions and lead the researchers to discover the concepts and incidents. Then, the researchers would compare this concept to another concept (see Shimura, 2001).

\section{Result And Discussion}

The goals of this research was to describe the strategic plans used by the novice and experienced teachers in order to transform their vulnerability into professional identity and to what extent this strategy impacted on their professional identity construction. Based on the findings, the researchers catalogued the results into two representative answers from the novice teacher (NT) and the experienced (ET) one.

\section{Novice and experienced teachers' strategic plans}

The participants believed that by doing critical reflections daily, they could be assisted in assessing their work and the classroom learning process. They do self reflections as an attempt to 
understand a situation and find the solution in every problem. This reflection is not for surface learning, but also for personal development as shown in the table below.

Table 1: Teachers' Reflection

\begin{tabular}{lll}
\hline Question & NT & ET \\
\hline Why do you want to be & "I am interested in English since & "I love being a teacher. Teaching is my \\
a teacher? & junior high. I had a dream to be a & passion. I was graduated from SPGA \\
& translator. Although I have some & (Catholic Education School) and I got \\
& teacher's relatives, but I never teaching basic and method there. Then \\
& thought that I will end up as a & I took a double degree in my bachelor \\
& teacher. Since there was no study. I was graduated in Law and \\
& English literature department in English Education. First, I studied in \\
the Nusa Cendana University, so I the Law department because my father & took English education. During is a Policeman, but then I believe \\
my study, I started to enjoy & English is important, so I took English \\
& teaching."
\end{tabular}

The teachers who participated in these interviews said that they had a passion for teaching and believed that mastering English was an important skill as global citizens. Both NT and ET said that their choice to be a teacher was not influenced by their family, but how they responded their environment's needs. In the local context, these teachers aimed to prepare Kupang's young generation to be able to compete in the global era. At the beginning, NT did not like being a teacher, but then she began to enjoy it because of the interaction with her pupils. From her teaching experiences, she started to develop her identity as a teacher. While ET, even though she had no teacher family background, developed passion in teaching and she followed her dream to be a teacher. Both of them might be different in responding to their experiences, but they hold a similarity on how they feel touched by the students and want to teach them. Their experiences resonate well with Harrison and Lee (2011), who argue:

"Experience allows for the building up of a mental model of the way the world (of the school/classroom) works, and subsequent experiences may conform to this particular structure without any change to the mental model (non-learning). Sometimes if the reaction to an experience is mental or physical discomfort, the personal trauma itself demands its own attention and thus prevents reflection" ( p.201).

The different experiences will lead them to the different responses. The researchers believed that the reason why these teachers wanted to be a teacher was important. By recognizing their purposes, teachers will be able to bounce back whenever they face problems.

\section{Teacher's Vulnerability}

In order to do their professional job, teachers are often confronted with many conflicting situations such as educational reforms, workload, curriculum adaptation and also the students' behavior. Vulnerability is considered not only an emotional experience but also a structural characteristic of the profession (Kelchtermans, 2013). This will challenge the teachers to keep their professionalism and at the same time demonstrate their ability to regulate their emotion. The capacity to know their strengths and weaknesses help teachers to deal with stress and also maintain a healthy relationship among themselves and with their students. How teachers regulate their emotion make them remain committed and able to teach to their best and well.

Table 2: Teachers' Expectations and Fears

\begin{tabular}{llll}
\hline Question & NT & ET \\
\cline { 1 - 2 } What do you expect & "As a teacher, I wish I can share & "I hope I can share my knowledge to my \\
and fear from being a & my knowledge to them and help & students and then, they can take the \\
teacher? & them fluent in English. The thing & point why they were learning English \\
& that I am worried about is when & today. I think I am not afraid of being \\
& my students have low teacher, because teaching is a noble job. \\
& achievement eventhough I did my & How we taught students from know \\
\hline
\end{tabular}


best to help them. You know, people easily judge the teacher when her students didn't pass the exam." nothing to know something. Its great." $\cdots$

"Honestly, I dont like administration work. This curicullum 13 is very tiring. How can we transfer our knowledge if teachers are busy with this paper works? What is the expected output?We are teaching hundreds of students, how can we assess each details of each person as objectively as possible?"

The table indicates that NT is worried about other people's evaluation of her performance and credibility as an English teacher. She attributed students' failure to herself even she knew that it was not always right. Many factors influence students' outcomes, like motivation, perseverance or social factors which are difficult to change or control. This kind of evaluation creates contradictory ideas among the teachers. When the students have a good score, teachers will feel proud and satisfy. Meanwhile, when students have low achievements, teachers tend to felt frustrated and blamed themselves. Even worst, they ascribe the student's results to factors beyond their efforts and control and hence have a discouraging impact on their motivation and finally their self-esteem. Her situation strengthens Kelchtermans' (2013) argument that the vulnerability results from "unfair evaluation of their work, doing injustice to their specific working conditions" (p.266).

On the other hand, ET experienced a conflict in her workload. ET was no longer worried about other people's assessments toward her teaching, but rather the administrative demands and the curicullum changes. ET was expected to be up-to-date and creative in answering all school's demands and regulations. As a teacher, she considered transferring knowledge to her students as her main responsibility instead doing on administration works.

"This curicullum 13 is very tiring. How can we transfer our knowledge if teachers are busy with this paper works?"

ET felt powerless in that situation and it influenced her performance. It can not be denied that their workplace conditions are imposed by regulation and particular infrastructure. Her experiences echoes Ball (2003, pp. 220-221) who believes that teacher performativity on strict standards and output measurements will strengthen their vulnerability experiences.

\section{Teachers' strategies to overcome negative impacts of vulnerability}

Vulnerability experiences can bring negative impacts "due to the feeling of powerlessness, betrayal or defenselessness in situations of high anxiety or fear" (Lasky, 2005, p.901). That is why, instead of being 'burnt-out', these teachers set strategies to overcome this vulnerable state and try to be in control of everything as shown in the table 3 below.

Table 3. Teachers' strategies to be ideal teacher

$\begin{array}{ll}\text { Question } & \text { NT } \\ \begin{array}{l}\text { What are the efforts you had to } \\ \text { become an ideal teacher? }\end{array} & \begin{array}{l}\text { "I don't know why these students } \\ \text { discussion and they were fun but }\end{array} \\ & \text { showed low scores in the exam. } \\ & \text { So, I decide to teach them } \\ & \text { privately and this strategy really } \\ & \text { helps. Besides, I keep improving } \\ & \text { myself and trying to find more } \\ & \text { information related to the } \\ & \text { technique of teaching English." }\end{array}$

ET
"I try my best in teaching
practises and making
documentation report. At the
beginning, we take care of the
administration before the initial
effective week. This strategy
makes it easier. All teaching
plans will be presented on MGMP
workshop before it presented in
the class. For the students'
assessments, I appreciate my
students who showed an
improvement. I can't force them
to be excellent or put the high


standard. If I do so, I lie to myself."

Considering their own limitations, both NT and ET keep improving themselves to be better. NT was afraid if her students failed in her class, so she was willing to learn how to teach English effectively and cope with her students. What she did supports Van der Want et al., (2018), who contend that the relationship between teacher and student plays important role to develop teachers' identity. She believed that her relationship with her students was quite good and they looked happy and enjoyed learning English with her. Her willingness to improve herself as a teacher is a sign that she is developing her professional identity.

However, ET realized that she was not good at administration work. ET was seeking help from her colleagues to generate some ideas and make lesson plans together. Through the teachers' meetings in the teachers' organization (MGMP), they discussed and set some strategies on how make everything balanced between the teaching activities and the documentation required in $\mathrm{K}-13$. Her belief about teaching reflects Ball (2003, p.226) who states that the education reform is not only change the organizations, but also change one's identity.

\section{The impacts on professional identity construction}

Teacher identity is represented through a dynamic interplay between efficacy, agency, and emotion in teacher self. When teachers are able to meet challenges, they can achieve their success in their life. Teachers are supposed to have a design about how to run and manage the class. When they faced a problem at teaching, they should find out what is wrong. Therefore, teacher identity will encourage teacher to find new ways or an suitable approach to teach (Day, 2018, p.61). NT and ET were asked about their view of a good teacher and how they saw themselves as a teacher as shown in the table below.

Table 4. Teachers' presumptions of their identity

\begin{tabular}{lll}
\hline Question & NT & ET \\
\hline What do you think about good & "For me, a good teacher is a "Good teacher is a teacher who \\
teacher? & teacher who has mastered the is loved by the students." \\
& knowledge and has an ability to \\
& simplify it and make it fun. So \\
& students will interest in learning \\
& English." \\
"I cannot say that I'm better now. "Sure. I learn from my & Iam still on process to be better. I experiences, the ups and the \\
Do you think that as a teacher & am new here and don't really downs, the success and the \\
now you are better than before? & know the new curicullum. So far, I failure. When I throw back, I \\
& haven't attending the K13's evaluate my teaching technique. \\
& training yet and the socialization Which one is the most suitable \\
& itself is unclear. However, we are approach for my students." \\
& required to apply the K13. So, I \\
& am still learning and adapting."
\end{tabular}

Both teachers had their own image of a good teacher. During the identity development process, each of them was copying different teachers, doing adaptations and adoptions and figuring out which one was the best strategy for them. This kind of modeling can be improved by learning through experience or self-study (Dimitrieska, 2018).

As a novice teacher, NT felt that she needed to learn more. On the other hand, ET with 14 years of the teaching experience felt positive and she was becoming a better teacher over time. Teachers as "reflective practitioners" (Harrison \& Lee, 2011, p.200) should recall their memory during certain kinds of significant incidents in school. The purpose of reflection is to emphasise teacher's awareness in developing their skill and construct their professional identity. Basically, reflection needs action to be followed up 


\section{Conclussion}

This research reveals that each teacher, both novice and experienced, should practice critical reflections and be honest with themselves in order to enable a comprehensive evaluation about what they should and should not do in teaching. This study attempted to discover the teachers' strengths and weaknesses and what strategies they set to transform their vulnerability into professional identity. In order to overcome the negative impacts of vulnerability, one should be able to regulate their emotion and seek help in the community or from other teachers.

In order to improve education quality, teachers are required to be able to bounce back and become resilient in every challenge. In order to develop an ability to deal with their vulnerability, both emotion and structural, teachers need to be motivated and possess integrity. Both new and experienced teachers are important elements at the school. A cooperative working condition can help each member of the school to grow together and this in turn will help them to develop their professional identity over time.

It is obvious that teachers' identity is not static but always develops through time. Many factors can shape their identity, be it internal or external. It may takes time to process, to do trials and errors, to adjust to teachers' self-characteristic and also the socio-culture where they work. During the process of identity development, teachers will face many frictions and obstacles, which may or may not accord with their own belief. Teachers' ability to juggle between those issues are expected lead them to personality changes, both in their mind and habits

\section{Reference}

Alsup, J. (2018). Teacher Identity Discourse as Identity Growth: Stories of Authority and Vulnerability. In P. A. Schutz, J. Hong, \& D. C. Francis (Eds.), Research on teacher identity (13-23). https://doi.org/https://doi.org/10.1007/978-3-319-93836-3

Ball, S. J. (2003). The teacher's soul and the terrors of performativity. Journal of Education Policy, 18(2), 215-228. https://doi.org/10.1080/0268093022000043065

Creswell, J. (2014). Research Design: Qualitative, Quantitative, and Mixed Methods Approaches (4th ed.). Sage Publication, Inc.

Day, C. (2018). Professional identity matters: Agency, emotions, and resilience. Research on Teacher Identity: Mapping Challenges and Innovations, (1), 61-70. https://doi.org/10.1007/978-3-31993836-3_6.

Dimitrieska, V. (2018). Becoming a Language Teacher: Tracing the Mediation and InternalizationProcesses of Pre-service Teachers. Research on Teacher Identity: Mapping Challenges and Innovations, (1), 157-168. https://doi.org/10.1007/978-3-319-93836-3_14

Friesen, M. D., \& Besley, S. C. (2013). Teacher identity development in the first year of teacher education: A developmental and social psychological perspective. Teaching and Teacher Education, 36, 23-32. https://doi.org/10.1016/j.tate.2013.06.005

Hamman, D., Gosselin, K., Romano, J., \& Bunuan, R. (2010). Using possible-selves theory to understand the identity development of new teachers. Teaching and Teacher Education, 26(7), 1349-1361. https://doi.org/10.1016/j.tate.2010.03.005

Harman, Benny. (2017). Mendikbud dan cara melihat pendidikan di NTT. Retrieved from https://nasional.kompas.com/read/2017/12/13/08472011/mendikbud-dan-cara-melihatpendidikan-di-ntt?page $=2$

Harrison, J. K., \& Lee, R. (2011). Exploring the use of critical incident analysis and the professional learning conversation in an initial teacher education programme. Journal of Education for Teaching, 37(2), 199-217. https://doi.org/10.1080/02607476.2011.558285

Jun, Y. dan, Issa, Feng, H. ai, \& Zheng Zhi Lian. (2018). Telling Stories: Understanding Teachers' Identity in a Context of Curriculum Innovation. In 0. Kwo (Ed.), Teachers as Learners (45-64). https://doi.org/10.1017/cbo9780511841057.010 
Kelchtermans, G. (2013). Who I am in how I teach is the message: Self-understanding vulnerability, and reflection. Advances in Research on Teaching, 19(April 2015), 379-401. https://doi.org/10.1108/S1479-3687(2013)0000019021

Kwo, O. (2018). From SET to STELT: Seeking the Meaning of Learning as a Community for Curriculum Development. In 0. Kwo (Ed.), Teachers as Learners (26th ed., 153-176). https://doi.org/10.1017/cbo9780511841057.010

Lasky, S. (2005). A sociocultural approach to understanding teacher identity, agency and professional vulnerability in a context of secondary school reform. Teaching and Teacher Education, 21(8), 899916. https://doi.org/10.1016/j.tate.2005.06.003

Liew, Warren Mark. (2018). From SET to STELT: Seeking the Meaning of Learning as a Community for Curriculum Development. In O. Kwo (Ed.), Lessons on Reform: A Story of Teaching as Lived Practise (245-268).

Miyagamwala, G. (2015). Emotional Intelligence and Teacher Effectiveness - An Analysis. The Business and Management Review, 5(4), 233-239.

Palmer, P. J. (2003). The Heart of a Teacher. In The Courage to Teach (9-33). https://doi.org/10.1080/00091389709602343

Pillen, M., Beijaard, D., \& den Brok, P. (2013). Tensions in beginning teachers' professional identity development, accompanying feelings and coping strategies. European Journal of Teacher Education, 36(3), 240-260. https://doi.org/10.1080/02619768.2012.696192

Seo, John. (2018). Menteri Muhadjir Effendy: Pendidikan di NTT urutan 3 terbawah. Retrieved from https://nasional.tempo.co/read/1048094/menteri-muhadjir-effendy-pendidikan-di-ntt-urutan-3terbawah

Shimura, K. (2001). Compare and Contrast of Grounded Theory and KJ Method, (1965), 46-57.

Sloan, K. (2006). Teacher Identity and Agency in School Worlds: Beyond the All-Good/All-Bad Discourse on Accountability-Explicit Curriculum Policies. In Curriculum Inquiry (Vol. 2).

Song, J. (2016). Emotions and Language Teacher Identity: Conflicts, Vulnerability, and Transformation. TESOL Quarterly, 50(3), 631-654. https://doi.org/10.1002/tesq.312

Tao, J., \& Gao, X. (2017). Teacher agency and identity commitment in curricular reform. Teaching and Teacher Education, 63, 346-355. https://doi.org/10.1016/j.tate.2017.01.010

Ulvik, M., \& Langrgen, K. (2012). What can experienced teachers learn from newcomers? Newly qualified teachers as a resource in schools. Teachers and Teaching: Theory and Practice, 18(1), 43-57. https://doi.org/10.1080/13540602.2011.622553

van der Want, A. C., den Brok, P., Beijaard, D., Brekelmans, M., Claessens, L. C. A., \& Pennings, H. J. M. (2018). Changes over time in teachers' interpersonal role identity. Research Papers in Education, 33(3), 354-374. https://doi.org/10.1080/02671522.2017.1302501 